\title{
БІОБЕЗПЕКА ТА БІОЕТИКА ЯК ЕЛЕМЕНТИ ПРОФЕСІЙНОГО СВІТОГЛЯДУ
}

\author{
Фешина М.O. \\ feshyna-fbmi@111.kpi.ua \\ Беспальва О.Я., к.б.н., с.н.с. \\ e.bespalova25.05@gmail.com \\ Бесараб О.Б., к.т.н. \\ o.besarab@kpi.ua \\ Національний технічний університет України \\ «Київський політехнічний інститут імені Ігоря Сікорського» \\ м. Київ, Україна
}

\begin{abstract}
Реферат - У наш час розвиток науки та промисловості потребує нових підходів до вирішення питань безпеки, особливо коли ие стосується життя людини. Негативні наслідки діяльності людини, особливо при роботі з різноманітними біологічними об'єктали, є потенційною загрозою як для життя та здоров'я людини, так і для навколишнього середовища, через яку розвиваються стандарти біобезпеки у всьому світі.

Стаття присвячена аналізу існуючих ризиків біобезпеки, у тому числі таким актуальним темам як редагування геному CRISPR, технологія рекомбінантних ДНК, вплив ГМО, клонування. Також акцентовано увагу на виникненні екологічних катастроф, які пов'язанні з недотриманням заходів з безпечного використання аспектів біобезпеки. Важливим аспектом, щзо піднімається в статті, є морально-етична складова поведінки професіоналів у сфері біотехнології, мікробіологї̈ та медичної біоінженерії, яка регулюється за допомогою існування кодексів. Стаття висвітлює актуальні проблеми біоетики та біобезпеки і наголошує на необхідності покращення відповідних правил, кодексів та вимог.
\end{abstract}

Ключові слова: біобезпека, біоетика, ризик, редагування геному, біотехнологія.

\section{I. ВСТУП}

Життя та здоров'я людини - головні, фундаментальні цінності. Діагностика різноманітних захворювань, аналіз біологічних матеріалів, які були взяті у людей або тварин, дослідження епідеміологічні, які $\epsilon$ дуже актуальними у наш час, а також дослідження наукові i фармацевтичні розробки - такі види операцій виконуються в біологічних лабораторіях в приватних або державних секторах економіки. Відповідні негативні наслідки для здоров'я людини $\epsilon$ потенційною загрозою, які стають поштовхом до покращення стандартів біобезпеки по усьому світу. Саме тому в цій статті розглядаються питання біобезпеки та аналіз потенційно небезпечних об'єктів та технологій, а також питання, пов'язані 3 медико-біологічними дослідженнями та їх впливом на життя людини в цілому та морально-етична складова поведінки професіоналів у сфері біотехнології, фармації та медицини.

\section{II. МЕТА РОБОТИ}

Огляд проблематики біобезпеки та біоетики, виявлення актуальних питань, які потребують вивчення та корегування використовуваних до них підходів.

Таблиияя 1.

Етіологічна структура внутрішньолабораторних інфекцій

\begin{tabular}{|c|c|c|c|}
\hline Захворювання & Кількість захворілих, $\%$ & Захворювання & Кількість захворілих, \% \\
\hline Бруцельоз & 10,8 & Висипний тиф & 3,2 \\
\hline Ку-лихоманка & 7,1 & Орнітоз & 3,0 \\
\hline Черевний тиф & 6,5 & Кокцидіомікоз & 2,4 \\
\hline Гепатит & 6 & Стрептококова інфекція & 2,0 \\
\hline Туляремія & 5,7 & Лептоспіроз & 2,2 \\
\hline Туберкульоз & 4,5 & Гістоплазмоз & 1,8 \\
\hline Дерматомікози & 4,1 & Шигельоз & 1,5 \\
\hline
\end{tabular}




\begin{tabular}{|c|c|c|c|}
\hline $\begin{array}{c}\text { Венесуельський кінський } \\
\text { енцефаліт }\end{array}$ & 3,6 & Сальмонельоз & 1,2 \\
\hline
\end{tabular}

\section{III. АНАЛІЗ НЕБЕЗПЕЧНИХ ВИРОБНИЧИХ ФАКТОРІВ}

Біобезпека - це забезпечення захисту біологічної різноманітності від потенційного ризику, який може виникати через живі генетично модифіковані організми, які були винаходжені за допомогою сучасних біотехнологічних методів. У той же час, лабораторії та виробництва, у яких працюють 3 різноманітними біологічними агентами, у тому числі 3 мікроорганізмами, які можуть виступати патогенами, вважаються зонами найбільш високого біоризику - і для кожної людини, i для усього людства. Перший випадок, коли в лабораторії були інфіковані наукові дослідники було задокументовано у 1885 р. - причиною став черевний тиф, - a вже ця інформація публікувалась у 1915 р. Було показано, що лабораторні інфекції можуть виникати більше ніж через 160 видів мікроорганізмів, більшість 3 яких $\epsilon$ бактеріями. 5400 лабораторних нещасних випадків було зафіксовано за останні 70 років, а також близько 100 епізодів, що зв'язані 3 попаданням $\mathrm{y}$ навколишне середовище патогенних біологічних агентів від біотехнологічних виробництв. Вважають, що лише $20 \%$ внутрішньолабораторних інфекцій $\epsilon$ встановленими, кількість 17 невідомих випадків становить $80 \%$. Причини інфікування встановлюють лише у $25 \%$ випадківДля усунення ризиків, пов'язаних із безпекою та ризиків нещасних випадків необхідно розробляти та суворо додержуватися правил безпечного поводження 3 небезпечними лабораторними патогенами й токсинами для запобігання їх випадковому поширенню у довкіллі та несанкціонованому доступу до них.

Ризик - це поєднання ймовірності виникнення безпосередньої загрози i наслідків настання події, пов'язаної 3 конкретним небезпечним фактором. Оцінювання ризику визначається як процедура, що аналізує певний процес чи ситуацію $з$ метою визначення ймовірності іiі виникнення та наслідків у разі настання певної несприятливої події.
Небезпечні виробничі фактори. Загалом, виділяють такі небезпечні і шкідливі виробничі фактори, 3 якими можна стикнутись у сфері біотехнології, фармації та медицини:

- біологічні (у першу чергу, це мікроорганізми: бактерії, віруси, рикетсії, спірохети, хламідіï, гриби, гельмінти, найпростіші та ін., а також продукти їх життєдіяльності; також макроорганізми: тварини, людина i продукти їх життєдіяльності; культури клітин і тканин, генетичні фрагменти, діагностичні препарати тощо);

- хімічні (реактиви, засоби для дезінфекції, канцерогенні, подразнювальні, сенсибілізувальні, мутагенні, алергенні та ін.);

- механічні, у тому числі й виробниче обладнання (обладнання, що працює під тиском, центрифуги, лабораторне скло, різальний, колючий інструментарій, гострі краї, задирки та ін.);

- фізичні (електричний струм, ультрафіолетове, електромагнітне випромінювання, недостатня освітленість, відхилення показників вологості й температури робочої зони від установлених норм, підвищена або знижена рухомість повітря, завеликий вміст шкідливих речовин у повітрі робочої зони, підвищений рівень шуму, гаряча вода та пара);

- людські (перевантаження персоналу різного походження - нервовопсихічні, фізичні, акти вандалізму та ін.);

- пожежонебезпека [2], [3]

Класифікація мікроорганізмів за групами ризику. Під час оцінювання ризиків та вибору методів захисту важливою умовою є звернути увагу на особливості біологічних агентів, 3 якими проводять роботу у лабораторії. Для полегшення цієї задачі були створені спеціальні міжнародні класифікації мікроорганізмів за групами ризику, які наголошують на таких пунктах:

1) патогенність біологічного агенту; 
2) шляхи передачі біологічного агенту та джерела інфекції. Треба відмітити, що на такі показники процесу інфікування мають вплив існуючі рівні імунізації місцевого населення, його густота i переміщення, наявність підходящих переносників хвороби та норми санітарного стану навколишнього середовища;

3) доступність i доказана ефективність заходів профілактики на місцях;

4) присутність у довкіллі відповідних хазяїв; За вже існуючою міжнародною класифікацією усі відомі мікроорганізми поділяють на 4 групи:

- Група ризику 1 (дуже низький або зовсім відсутній індивідуальний i суспільний ризик) об'єднує мікроорганізми, які не можуть спричинити захворювання у людини або тварини через відсутність патогенності. Наприклад: Bacillus subtilis, Naegleria gruberi, вірус собачого гепатиту та ін.

- Група ризику 2 (помірний індивідуальний ризик, низький суспільний ризик) об'єднує біологічні агенти, які можуть можуть бути причиною інфекування людини або тварини, але навряд чи будуть становити серйозну небезпеку для дослідників, що працюють у лабораторії, суспільства, свійської худоби або оточуючого середовища. При цьому до таких мікроорганізмів існують методи профілактики та лікування, які таким чином ефективно запобігають ризику поширення таких захворювань у популяції. Наприклад: Salmonellae spp., Toxoplasma spp., збудник гепатиту В та кору.

- Група ризику 3 (високий індивідуальний ризик, низький суспільний ризик) включає у себе патогенні організми, які як правило стають причиною серйозних захворювань людини або тварини, але хвороба однісї особи не інфікую іншу. При цьому повинні існувати способи ефективного лікування та профілактики хвороби, викликаної представниками цієї групи.
Наприклад: M. tuberculosis, Coxiella burnetti.

- Група ризику 4 (високий індивідуальний і суспільний ризик) об'єднує мікроорганізми, які мають здатність викликати серйозні захворювання людей або тварин, при цьому вони активно розповсюджуються від інфікованої людини до здорової прямо чи опосередковано. Методи ефективного лікування та превентивні заходи, як правило, не доступні. Наприклад: вірус лихоманки Ебола, вірус лихоманки РіфтВаллі.

В Україні існує своя національна класифікація мікроорганізмів, яка біла сформована ще у Радянському Союзі i продовжує застосовуватись до сих пір. Ця систематизація відрізняється від міжнародної, але також ділить мікроорганізми на 4 групи:

- I група мікроорганізмів, включає Yersinia pestis, віруси Марбург та Ебола, віруси Ласса, Хуанін та Мачупо, вірус натуральної віспи та ін.;

- II група - B. anthracis, B. abortus, B. melitensis, B. suis, $35 \mathrm{~F}$. tularensis, $L$. pneumophilla, L. interrogans, P. mallei, $P$. pseudomallei, $V$. cholera, $R$. typhi, вірус жовтої гарячки, вірус гепатиту C, віруси комплексу кліщового енцефаліту та ін.;

- III група - B. pertusis, B. recurrentis, Campylobacter spp., C. botulinum, $C$. tetani, C. diphteriae, $H$. pylori, Leptospira spp., L. monocitigenes, $M$. leprae, M. tuberculosis, N. gonorrhoeae, $N$. meningitides, $S$. paratyphi A ma $B, S$. typhi, Shigella spp., T. pallidum, $Y$. pseudotuberculosis, віруси грипу А, В та С, віруси герпесу простого I та II типів та ін.;

- IV група - A. aerogenes, B. cereus, Bacteroides spp., Borrelia spp., $B$. bronchoseptica, Citrobacter spp., $C$. perfringens spp., E. coli, Candida spp., аденовіруси усіх типів, реовіруси людини, віруси Коксакі груп А і В та ін. [4]

Також ВОО3 було запропоновано систематизувати мікробіологічні лабораторії 
враховуючи їх функції, конструкції, обладнання, засоби, що в них використовуються, практики і оперативні порядки, необхідних для роботи 3 біологічними агентами, що належать до різних груп ризику. Згідно 3 цією систематизацією існує 4 типи лабораторій: базовий рівень біобезпеки 1 (BSL-1), базовий рівень біобезпеки 2 (BSL-2), ізольований рівень біобезпеки 3 (BSL-3) і максимально ізольований рівень біобезпеки 4 (BSL-4).

Таблиия 2

Взаємозв'язок груп ризику та рівнів біобезпеки, практики та обладнання

\begin{tabular}{|c|c|c|c|c|}
\hline $\begin{array}{l}\text { Група } \\
\text { ризику }\end{array}$ & $\begin{array}{c}\text { Рівень } \\
\text { біологічної } \\
\text { безпеки } \\
\end{array}$ & Тип лабораторії & $\begin{array}{c}\text { Особливості лабораторного } \\
\text { захисту }\end{array}$ & Захисне обладнання \\
\hline 1 & $\begin{array}{c}\text { Базовий рівень } \\
\text { біологічної } \\
\text { безпеки } 1 \\
\end{array}$ & $\begin{array}{l}\text { Навчальні та } \\
\text { дослідницькі }\end{array}$ & $\begin{array}{c}\text { Застосування «правильних } \\
\text { мікробіологічних технік }\end{array}$ & Відсутнє \\
\hline 2 & $\begin{array}{l}\text { Базовий рівень } \\
\text { біологічної } \\
\text { безпеки } 2\end{array}$ & $\begin{array}{c}\text { Бактеріологічні } \\
\text { лабораторії } \\
\text { лікувальних закладів; } \\
\text { діагностичні, } \\
\text { дослідницькі }\end{array}$ & $\begin{array}{c}\text { Застосування «правильних } \\
\text { мікробіологічних технік у } \\
\text { поєднанні із захисним одягом } \\
\text { та маркуванням біобезпеки }\end{array}$ & $\begin{array}{l}\text { Бокс біологічної } \\
\text { безпеки }\end{array}$ \\
\hline 3 & $\begin{array}{l}\text { Ізольований } \\
\text { рівень } \\
\text { біологічної } \\
\text { безпеки } 3\end{array}$ & $\begin{array}{c}\text { Спеціальні } \\
\text { діагностичні та } \\
\text { дослідницькі } \\
\text { лабораторії }\end{array}$ & $\begin{array}{c}\text { Застосування «правильних } \\
\text { мікробіологічних технік у } \\
\text { поєднанні із спеціальним } \\
\text { одягом, маркуванням } \\
\text { біобезпеки, контрольованим } \\
\text { доступом та спрямованим } \\
\text { потоком повітря } \\
\end{array}$ & $\begin{array}{c}\text { Бокс біологічної } \\
\text { безпеки та інші засоби } \\
\text { первинного захисту }\end{array}$ \\
\hline 4 & $\begin{array}{c}\text { Максимальний } \\
\text { рівень } \\
\text { біологічної } \\
\text { безпеки } 4\end{array}$ & & $\begin{array}{c}\text { Застосування «правильних } \\
\text { мікробіологічних технік у } \\
\text { поєднанні із спеціальним } \\
\text { одягом, маркуванням } \\
\text { біобезпеки, контрольованим } \\
\text { доступом та спрямованим } \\
\text { потоком повітря, наявність } \\
\text { передбоксника, приймання } \\
\text { душу перед виходом та } \\
\text { спеціальна утилізація } \\
\text { відходів }\end{array}$ & $\begin{array}{c}\text { Бокс біологічної } \\
\text { безпеки III класу, } \\
\text { позитивний тиск на } \\
\text { вході, або бокс } \\
\text { біологічної безпеки II } \\
\text { класу, позитивний тиск } \\
\text { на вході та подвійні } \\
\text { двері, автоклав, } \\
\text { фільтрування повітря } \\
\text { на виході }\end{array}$ \\
\hline
\end{tabular}

Іноді вважають, що приналежність біологічного агенту до певної групи ризику (до другої, наприклад) вимагає наявності лабораторії з аналогічним рівнем біобезпеки (тобто другого рівня біологічної безпеки). Це твердження $€$ помилковим. Проте, враховуючи вимоги певних процедур, що мають бути виконані з таким біологічним агентом, доцільним може бути використання більш високого або більш низького рівня біобезпеки.

Окрім потенційно небезпечних біологічних об'єктів, існують багато технологій, які використовуються у науково-дослідних та виробничих процесах і які також можуть становити ризики і призводити до певних негативних наслідків. Розглянемо деякі з них детальніше нижче [5]

\section{VI. РЕДАГУВАННЯ ГЕНОМУ CRISPR}

Перший локус CRISPR був виявлений у бактерії Escherichia coli в 1987 році групою японських вчених. Вони помітили в геномі цієї бактерії повторювані елементи, розділені послідовностями, що не повторювались (спейсерами). Масштабне вивчення CRISPR почав іспанський дослідник Франсиско Мохіка в 1993 році, який виявив подібні послідовності в геномі археї Haloferax mediterranei. Мохіка продовжив пошуки CRISPR в геномах інших мікробів, і до 2000 року він виявив їх у 20 мікроорганізмів, в тому числі чумної палички Yersinia pestis i інших патогенів. У 2006 році була розроблена класифікація відомих CRISPR i запропонований можливий механізм роботи заснованого на CRISPR адаптивного 
імунітету. У 2007 році дослідницькою групою на чолі з Філіпом Хорватом було остаточно встановлено i експериментально доведено участь CRISPR в забезпеченні роботи специфічного до послідовностей-мішеней адаптивного імунітету.

До відкриття функцій і механізмів дії систем CRISPR-Cas в якості методів для локусспецифічного редагування геному найбільш інтенсивно розроблялися методи, засновані на використанні нуклеаз, що містять цинкові пальці. Однак в 2012-2013 роках в генній інженерії з'явилися принципово нові методи маніпулювання генетичним матеріалом, засновані на застосуванні систем CRISPRCas. Дані методи придатні для цілеспрямованого редагування геномів як прокаріот, так i еукаріот. Методика CRISPR/Cas9 дає змогу виявити чітко визначену послідовність нуклеїнової кислоти в ДНК клітини і «вирізати» іiі. Ця технологія була використана для експериментів, що мали на меті лікування різноманітних захворювань. Вченими було протестовано цю методику на ембріональних стовбурових клітинах миші, клітинах кісткового мозку миші та епітеліальних клітинах сітківки людини. Використання системи CRISPR призводило до зміни та вирізання ДНК. Ще одним фактором підвищеної небезпеки цього методу виявилось те, що подібні пошкодження було неможливо виявити традиційними способами. Застосування CRISPR-Cas у мікроорганізмів дозволяє модифікувати їх метаболічні шляхи, що відкриває можливості для розвитку нових біотехнологічних стратегій. Крім того, важливе значення для біотехнології має створення штамів технологічно важливих бактерій, стійких до різних фагів за рахунок CRISPR-Cas.

У квітні 2015 року група вчених з Китаю опублікувала результати свого дослідження, в якому за допомогою CRISPR-Cas9 були відредаговані геноми людських ембріонів. Однак точність редагування в цьому експерименті була дуже низька, а сам експеримент був неоднозначно сприйнятий науковим співтовариством. У листопаді 2018 року стало відомо, що команді китайських вчених під керівництвом Хе Цзянькуя вдалося створити перше в світі людей 3 штучно зміненими генами (відключений CCR5) - двох дівчаток-близнят, які, як передбачається, несприйнятливі до вірусу імунодефіциту людини. Даний експеримент був розкритикований через порушення численних наукових і етичних правил. [6, 7, 8]

\section{V. БІОЛОГІЧНА БЕЗПЕКА I ТЕХНОЛОГІЯ РЕКОМБІНАНТНИХ ДНК}

Технологія рекомбінантних ДНК полягає в з'єднанні генетичного матеріалу, отриманого 3 різних джерел, і створенні таким чином генетично модифікованих організмів (ГМО), можливо, ніколи раніше не існували в природі. На перших етапах роботи молекулярні біологи висловлювали побоювання 3 приводу того, що такі організми можуть мати непередбачувані i небажаними властивостями, які можуть представляти біологічну небезпеку за стінами лабораторій. Технологія рекомбінантних ДНК вже справила величезний вплив на біологію і медицину i, можливо, надасть ще більший вплив тепер, коли синтезована нуклеотидних послідовність повного людського геному. Десятки тисяч генів невідомого досі призначення будуть вивчені на підставі використання технології рекомбінантної ДНК. Генна терапія може стати загальноприйнятою при лікуванні певних захворювань і цілком ймовірно, що 3 використанням технологій генної інженерії будуть створені нові вектори для перенесення генів.

Вірусні вектори, наприклад, аденовірусні вектори, використовуються для перенесення генів в інші клітини. У таких векторах відсутні певні гени реплікації вірусу, і вони розмножуються в клітинних лініях, що заповнює цей недолік. Штами таких векторів можуть бути заражені вірусами, здатними до реплікації, що генеруються рідкісними спонтанними рекомбінаціями в розмножуються клітинних лініях, або можуть виникати через недостатню очищення. Для звернення 3 такими векторами потрібно той же рівень біологічної безпеки, що і для поводження 3 батьківським аденовірусом, 3 якого вони вилучені. 
Багато модифікації не охоплюють гени, продукти яких в своій основі шкідливі, але побічні ефекти можуть виникнути i в результаті зміни існуючих непатогенних i патогенних ознак. Модифікація нормальних генів може привести до зміни патогенності. $[9,10]$

\section{VI. ВПЛИВ ГМО}

Рекомбінантні бактерії використовуються вже більше 45 років: у 1973 було створено перші $з$ них; це була $E$. coli, яка через іiі модифікацію експресувала ген Salmonella. У 1975 році Герберт Бойєр була створена перша компанія, яка у своїй роботі застосовувала технологію рекомбінантних ДНК Genentech. Вже у 1978 Genentech об'явила про створення лінії на основі вже використаної E. coli, мета якої була секреція білку людського організму - інсуліну. Широке використання технологій, пов'язаних з ГМО у промисловості почалось в середині 1990-х. 3 тих пір кожного року ГМО використовуються все більше. Вони набули актуальності в біологічних та медичних дослідженнях, у фармакологічному виробництві, генній терапії та у сільському господарстві. Також за участю ГМО стало можливим вивчення та аналіз закономірностей розвитку певних хвороб, а також процесів старіння та відновлення. Генна інженерія дуже широко застосовується у сільськогосподарській промисловості для створення нових сортів рослин, які були б стійкі до несприятливих умов довкілля, хімічних речовин типу гербіцидів та шкідників рослин, або ж для створення рослин, що мають покращені ростові та смакові якості. Також 3 початку нового століття набуло використання трансмодифікованих тварин. Так, наприклад, у лютому 2009 FDA було схвалено створення перших біологічних ліків, основою яких був генетичний матеріал кози. У наш час одним 3 найперспективніших напрямків генної інженерії названо «вирощування ліків на фермі», тобто процес отримання 3 молока тварин зі зміненим генетичним кодом різноманіття рідких білків або білків, які отримати іншим методом було б значно дорожче, що широко застосовуються у медицині.

Але існують й певні ризики та побоювання щодо використання ГМО та його впливу на людське здоров'я. Особливо ці побоювання стосуються продуктів харчування, що були отримані з використанням ГМО.

Один 3 таких можливих ризиків при споживанні ГМО є можлива алергенність їжі. При модифікації геному рослин новий ген додають у вже існуючий генетичний код рослини, то у результаті рослина синтезує новий білок, який може виявитися новим серед продуктової корзини певної людини. Внаслідок цього стає неможливим стовідсотково визначити алергенність продукту харчування, спираючись при цьому лише на минулий досвід. Вважається, що кожний новий протеїн може запустити каскад алергічних реакцій, якщо на його поверхні при кінцевій структурі $\epsilon$ специфічні місця для зв'язування до $\operatorname{IgE}$ антитіл. Встановлено, що схильність до появи алергійної реакції залежить від генетичної спадковості. Нові можливі алергени можуть бути утворені також у сортах конвенційної селекції, але відстежити такі алергени $\epsilon$ непростим завданням, до того ж, не існує передбаченої процедури допуску конвенційних сортів, при якій би проводився аналіз на можливу алергенність. Існують підтверджені випадки, коли продукт під час вдосконалення певних властивостей почав проявляти можливу алергенність, i тоді цей продукт було виведено з ринку. Наприклад, в 1996 році компанія Pioneer Hi-Bred займалася розробкою кормової сої зі зміненим амінокислотним складом, а саме 3 додатковою кількістю метіоніну. Щоб досягти цієї мети у якості додаткового гену використали ген бразильського горіху, що, як дізналися пізніше, виявляв алергійні якості. У 2005 році компанія CSIRO займалася розробкою сортів гороху, що були б стійкими до шкідників, але експерименти показали, що робота, яка була проведена, мала негативний вплив на лабораторних мишей, а саме була причиною появи алергійних вражень легень. У цьому випадку робота над цим проектом була також припинена.

Окремі синтезовані продукти генів, що додаються до генетичного коду i 
переносяться у біологічний організм можуть проявляти токсичні властивості. В 1999 році була випущена стаття Арпада Пуштаї (Árpád Pusztai) яка наголошувала про токсичність ГМО картоплі для щурів. У рослину було вбудовано ген лектину 3 проліска 3 метою підвищити стійкість картоплі до нематод. У наш час щоб випустити генно модифіковані рослини на ринок, повинний бути зроблений хімічний аналіз речовин в складі отриманого організму у порівнянні $з$ вже існуючими i допущеними продуктами та проведені досліди на експериментальних тваринах. Станом на 2010 рік інших науковозадокументованих прикладів токсичності i негативного впливу на організм трансгенних продуктів, що допущені до комерційного вирощування, не спостерігалось. До 2007 року було випущено близько 270 наукових робіт, які демонструють безпеку продуктів, отриманих шляхом редагування геному.

Окремим питанням стоїть горизонтальний перенос генів від ГМО до споживача. Розвиток технології генної модифікації i вживання генетично-модифікованої їжі стимулювали ряд експериментів 3 вивчення долі вжитої з продуктами ДНК в травній системі. Відомо, що під час травлення 95\% ДНК розщеплюється до окремих нуклеотидів, у той час як $5 \%$ у вигляді ділянок розміром від 100 до 400 нуклеотидів потрапляють до кишківнику. Так як під час створення ГМО широко застосовують конститутивні промотори, які здатні активувати певні гени у тваринних клітинах у тому числі, то існує ризик, що ділянки ДНК, які відповідають за кодування промоторів, ввійдуть в генетичний код людини і стануть причиною активації сплячих генів. Досліди на лабораторних тваринах (а саме на мишах) показують, що неперетравлені нуклеїнові кислоти будь-якої іжі можуть потрапляти у кров, попадати в печінку i навіть проникати крізь плацентарний бар'єр. Але не зважаючи на ці хвилювання до сих пір не було зареєстровано жодного подібного випадку.

Ще одною проблемою, пов'язаною 3 використанням ГМО, є потенційний вплив на ряд екосистем. Вбудовані гени можуть впливати на оточуюче середовище, якщо вони будуть примножуватись i будуть присутні постійно в природних популяціях.
Такі ж проблеми виявлені й у конвенційній селекції. Багато рослин що є одомашненими людиною можуть перехрещуватись 3 дикими родичами, коли вони знаходяться близько один до одного, і тоді гени культивованих рослин можуть бути передані гібридам. Не зважаючи на те що гібриди між дикими та використованими людиною рослинами не $є$ рідкими, найчастіше ці гібриди не $\epsilon$ фертильними через поліплоїдію i не зберігаються в екосистемах протягом довгого часу після того, як одомашнений сорт вилучається 3 культивування. Проте можливість негативного впливу залишається. Іноді пилок з генно модифікованих рослин може поширюватися на велику відстань 3 вітром і запилювати інші рослини, що у свою чергу може ускладнити оцінку можливого збитку від перехресного запилення, так як потенційні гібриди будуть розташовані на великій відстані від дослідних полів. Щоб розв'язати подібні випадки пропонується використання систем, які призначені для запобігання передачі модифікованих генів, наприклад, термінаторні технології та методи генетичної трансформації виключно хлоропластів - тоді пилок не буде трансгенним. [11, 12, 13, 14]

\section{VII. ДОСЛІДИ НАД ТВАРИНАМИ 3 ТОЧКИ ЗОРУ ЕТИЧНИХ НОРМ}

Зазначено, що задля дослідів людини у світі кожного року використовується 50-100 мільйонів хребетних тварин. Не дивлячись на використання безхребетних тварин для великої кількості експериментів у якості модельних організмів, їх використання ніяк не контролюється, а облік кількості не ведеться. Досліди ставляться до генетики, біології розвитку, етології i прикладних досліджень типу біомедичних, ксенотрансплантації, тестування ліків, токсикологічних дослідів (в тому числі тестування косметики і побутової хімії). Не усі 3 цих дослідів $\epsilon$ етично дозволеними. Філософ Бернард Роллін 3 Державного університету Колорадо, головний автор двох федеральних законів США, що регулюють питання знеболювання в дослідах на тваринах, пише, що до 1980-х дослідники 
залишалися невпевнені в тому, чи відчувають тварини біль.

Один 3 найбільш відомих інцидентів 3 дослідами на тваринах в США стався в місті Сілвер-Спрінг, Меріленд. Експерименти на мавпах ставилися під керівництвом Едварда Тауба - невролога, видаляти мавпам спинальний ганглій, за допомогою якого команди з їх мізків доходили до рук. Тауб був заарештований і звинувачений в жорстокому поводженні 3 тваринами (перше подібне звинувачення в США вченому). Однак в подальшому суд штату Меріленд ухвалив, що законодавство про заборону жорстокого поводження в тваринами штату не поширюється на лабораторії, що фінансуються з федерального бюджету. У травні 1984 року активісти «Фронту звільнення тварин» таємно проникли в лабораторію 3 вивчення травм голови Пенсильванського університету, де дослідник Томас Дженнареллі викликав травми головного мозку в мавп, закріплюючи їx голови в спеціальному шоломі і завдаючи ударів гідравлічним молотом. В результаті секретар Національного інституту здоров'я Маргарет Хеклер призупинила фінансування досліджень Дженнареллі. Департамент сільського господарства США також знайшов 74 порушення і стягнув штраф з університету. Через кілька місяців президент Рейган затвердив поправки до закону про благополуччя тварин 1985 року, зажадали поліпшення умов утримання лабораторних тварин.

Міжнародна асоціація проти хворобливих експериментів на тварин, (англ. International Association Against Painful Experiments on Animals, IAAPEA) була створена в 1969 році як недержавна міжнародна організація, чиїм завданням став розвиток гуманних методів дослідження, альтернативних дослідам на тваринах. Для досягнення своїх цілей Асоціація реалізує кілька ініціатив, основною стратегією яких $є$ заохочення і підтримка гуманних методів дослідження. В рамках цієї ініціативи було, зокрема, запущений проект Humane Research Donor Card, щоб серед іншого забезпечити банки тканин людськими матеріалами, доступними для дослідження в будь-який момент, коли це необхідно, що, в свою чергу, скорочує число піддослідних тварин і витрати на дослідження , а також забезпечує більш надійні результати і безпеку препаратів для людини. Проект був активно підтриманий багатьма вченими, включаючи хірургів, невропатологів і дослідників лікарських засобів. [15, 16, 17, 18]

\section{VIII. ВИКОРИСТАННЯ ІНСЕКТИЦИДІВ ТА МІНЕРАЛЬНИХ ДОБРИВ}

Сільськогосподарська промисловість потребує великої підтримки від людини задля свого функціонування. Одними з допоміжних речовин у цьому $є$ інсектициди, наприклад. Це хімічні препарати, призначені для знищення шкідливих комах. Але деякі з них вбивають або завдають шкоди іншим істотам крім тих, для кого вони призначені. Як конкретний приклад можна розглянути використання ДДТ дихлордифенілтрихлорметилмета́ну. Це класичний приклад інсектициду. За формою ДДТ є біла кристалічна речовина, що не має смаку і майже без запаху. У 1939 році швейцарський хімік Пауль Мюллер (Paul Müller) виявив у 4,4-ДДТ (ДДТ) інсектицидні властивості. Однак Мюллер був першовідкривачем самого речовини, перші відомості про ДДТ були опубліковані ще 1873 в «Доповідях німецького хімічного товариства». В 1942 році були проведені перші польові випробування нового контактного інсектициду на мухах, колорадському Жука, попелицях, молі i багатьох інших шкідників. В ході дослідів були випробувані різні препаративні форми ДДТ: розчини, емульсії, гранули. Результати дослідів виявилися приголомшливими і через кілька місяців ДДТ надійшов у продаж. ДДТ $\epsilon$ інсектицидом зовнішньої дії, тобто викликає загибель при зовнішньому контакті через поразку нервової системи комахи. Крім побутової користі та сільськогосподарської як засіб боротьби з рядом шкідників, ДДТ має перелік загальновизнаних заслуг світового масштабу, серед них можна виділити запобігання епідемії тифу в Неаполі у 1944 році, стрімке зменшення випадків малярії у Індії, Греції, Італії та ряді інших країн, а також застосування ДДТ в сільському господарстві значно підвищило врожаї і було ключовим фактором у розвитку так званої 
«Зеленої революції». Пік ейфорії щодо використання ДДТ припав на 1962 рік, коли в світі було застосовано за призначенням 80 тисяч тонн ДДТ, а зроблені 82 тисячі тонн. Потім об'єм виробництва і користування ДДТ стали знижуватись. Причиною цього стала кампанія - обговорення про шкідливий вплив ДДТ, яка була розпочата книгою американської письменниці Рейчел Карсон «Мовчазна весна», в якій Карсон стверджувала, що застосування ДДТ шкідливо впливає на репродуктивну функцію у птахів. Ця книга викликала широкий резонанс в США. Сторону Карсон взяли різні екологічні організації, такі як Фонд захисту навколишнього середовища (англ. Environmental Defense Fund), Національна федерація живої природи (англ. National Wildlife Federation). Значно пізніше було встановлено, що ДДТ викликає стоншення шкаралупи яєць і загибель ембріонів. Однак різні групи птахів сильно розрізняються по своїй чутливості до ДДТ; хижі птахи проявляють найбільшу чутливість, і в природних умовах часто можна виявити виражене стоншення шкаралупи, тоді як курячі яйця порівняно нечутливі.

ДДТ є дуже стійким до розкладання: його не бере ні зависока температура, ні ферменти, головною роллю яких $€$ знешкодженням чужорідних речовин, ні вплив сонячного випромінювання не мають ефективного впливу на процес розкладання ДДТ. Наслідком цього $є$ те, що коли ДДТ виявляється у навколишньому середовищі, то воно так чи інакше потрапляє в харчовий ланцюг. Розрахунок Дамена і Хейса (1973 рік) показав, що на кожній ланці харчового ланцюга відбувається збільшення вмісту ДДТ в 10 разів. Висока розчинність в жирах i низька розчинність в воді зумовлюють затримку ДДТ в жировій тканині. Швидкість, 3 якою ДДТ накопичується в організму залежить просто від виду організму, від часу впливу та концентрації, а також від умов довкілля. Високий ступінь утримання ДДТ означає, що токсичні ефекти у організмів можуть виникати з затримкою за часом, а також на значному географічному видаленні від місця впливу. Наявні дані про наслідки токсичного впливу ДДТ на людину можна узагальнити наступним чином. ДДТ володіє гострим токсичним впливом на людину: в невеликих i середніх дозах викликає отруєння, у великих дозах може викликати смерть. Дослідження, яке проводилося співробітниками школи громадського здоров'я Колумбійського університету протягом шістдесяти років, показало, що через 40 років після впливу ДДТ у жінок розвиваються симптоми раку молочної залози. З'ясувалося, що всі жінки, які так чи інакше зазнали впливу ДДТ у високій концентрації, стикалися згодом 3 раком молочної залози. Загалом механізм впливу ДДТ на довкілля може бути представлений подібним чином: під час застосування ДДТ у любому випадку потрапляе в харчовий ланцюг, потім він не піддається нейтралізації, а навпаки накопичується в живих організмах. До того ж ДДТ токсично впливає на живі організми різних рівнів харчового ланцюга, $\mathrm{i}$ це призводить до пригнічуваної дії на життєво важливі функції, або навіть до смерті живого організму. Цей вплив може призводити до зміни видового складу флори і фауни аж до повного викривлення харчового ланцюга, що, в свою чергу, може викликати загальний харчової криза і спричинити за собою незворотні процеси деградації екосистеми Землі. [19, 20]

\section{ІХ. КЛОНУВАННЯ}

Клонування (в біології) - це процес отримання особин 3 однаковою або практично ідентичною ДНК, як природним, так і штучним шляхом. Термін «клонування» також використовують і по відношенню до клітин багатоклітинних організмів. Вівця Доллі - перша клонована тварина, яка була відтворена шляхом переносу ядра соматичної клітини в цитоплазму яйцеклітини. Вівця Доллі була генетичною копією вівці - донора клітини.

Джерелом генетичної інформації яку піддали клонуванню були соматичні (диференційовані) клітини, а не гамети чи стовбурові клітини. Частина фахівців припускає, що причиною ранньої смерті цієї клонованої вівці могли стати теломери, адже зазвичай ці тварини живуть 10-12 років, у той час як Доллі прожила 7. Потім утворилась інша група вчених, котрі вважали, що 
клонування призевело до прискореного старіння. Клонування може бути використано як для збереження вимираючих видів, так і для відтворення трансгенних, штучних видів і порід. Але такі прості методи, як ті, що застосовувалися при отриманні Доллі, не можуть вирішити проблему генетичного різноманіття. Для iї вирішення необхідно розробляти більш дорогі і гнучкі підходи. Окремо стоїть питання клонування людини прогнозована методологія, яка полягає в створенні ембріона i подальшому вирощуванні 3 ембріона людей, що мають генотип тієї чи іншої колись існувавшої людини. Небезпека полягає у тому, що існує великий відсоток невдалих спроб при клонуванні, що може призвести до появи неповноцінних людей. А також питання батьківства, материнства, успадкування, шлюбу і багато інших. Також 3 точки зору основних світових релігій (християнство, іслам, буддизм) клонування людини є або проблематичним актом, або актом, що виходить за рамки віровчення і вимагає у богословів чіткого обгрунтування тієї чи іншої позиції релігійних ієрархів. Саме через це у даний час в світі активно розгорнувся процес криміналізації клонування людини. $[21,22]$

\section{Х. ЕКОЛОГІЧНІ КАТАСТРОФИ: ДЕПОПУЛЯЦІЯ ГРИФІВ В ПІВДЕННІЙ A3IÏ}

3 другої половини 1990-х років відбулося різке катастрофічне скорочення популяцій грифів різних видів. Причини явища до кінця не з'ясовані, проте більшість досліджень приходять до висновку, що масова загибель грифів в тій чи іншій мірі пов'язана 3 поширенням протизапального препарату диклофенак, який використовувався в селянських господарствах Індії, Пакистану, Непалу і Бангладеш. Особливо небезпечними були для грифів ДДТ і гексахлоран, які в Індії були заборонені, але проте продовжували використовуватися досить широко. Токсична дія згаданих інсектицидів називалося вченими як одна з основних причин зниження народжуваності у грифів. Переважна більшість обстежених мертвих грифів загинули від вісцеральної подагри птахів, яка була викликана гострою нирковою недостатністю, а вона, в свою чергу, була обумовлена потраплянням в організм диклофенаку. Диклофенак спочатку застосовувався в лікуванні ревматологічних захворювань, де важливі обидва компонента: виражений протизапальний i потужний аналгетичний ефект. У 2004 році в Індії вченими була запущена кампанія, спрямована на добровільну відмову від використання диклофенаку в тваринництві. Екологічні наслідки зникнення грифів були досить значні: істотно гірше стала епідеміологічна обстановка в сільській місцевості, де нікому стало знищувати розкладаються туші тварин. Звільнилася екологічну нішу пожирачів падали почали заповнювати дикі (вдруге здичавілі) собаки, поголів'я яких збільшилася в кілька разів. Незважаючи на кризу стерв'ятників, диклофенак залишається доступним в інших країнах, включаючи багато країн в Європі. Він був спірно схвалений для застосування у ветеринарії, в Іспанії в 2013 році і продовжує бути доступним, незважаючи на те, що Іспанія $\epsilon$ домом для близько $90 \%$ європейського населення грифа і незалежне моделювання показує, що препарат може зменшити популяцію грифів на 1-8\% на рік, [23, 24]

\section{ХІ. МОРАЛЬНО-ЕТИЧНА СКЛАДОВА ПОВЕДІНКИ ПРОФЕСІОНАЛІВ У СФЕРІ БІОТЕХНОЛОГІї}

Для регулювання морально-етичної поведінки професіоналів насамперед створюють етичні кодекси, дотримання котрих є обов'язковим для роботи у певних сферах. Розглянемо деякі з них.

Етичний кодекс ученого Украйни - у ному наводяться та формулюьбся загальні етичні принципи. При здійсненні своєї професійної діяльномті, їx необхідно дотримуватися кожному науковцеві та викладачеві. Він відішрає віжливу роль при формуванні професійних відносин між представниквми наукової спільноти, як з суспільством, так i між собою. Етияний кондек України заснований на розумінні, що належна практика в науковій сфері сприяє довірі серед науковіої спільноти та впливає на довуру суспільства до їх роботи, що явдяється 
незамінною складовою для розвитку науки. [25]

Необхідно усвідомлювати, що кожен вчений, в першу чергу, відповідає морально за результати своєї наукової діяльності, які впливатимуть на розвиток суспільства та навколишнього середовища. Одним 3 основних завдань вчених, відповідно до кодеюку, являється запобігання отриманню результатів які суперечать принципам гуманізму, тобто наукова діяльність та проведення наукових досліджень не має права здійснюватися в супереч прав людини та ображали iï гідність. При проведенні медико-біологічних дослідженнь необхідно приділяти особливу увагу принципами біоетики. [25] Це - основні положення даного кодексу, що був сформований і схвалений постановою загальних зборів НАН України від 15.04.2009.

Етичний кодекс лікаря Украӥни був прийнятий на $\mathrm{X}$ з'їзді Всеукраїнського лікарського об'єднання, який відбувся у Свпаторії 24-27 вересня 2009 р. У жовтні 2008 р. Україна стала членом Всесвітньої медичноїа асоціації. 3 тих пір вітчизняний етичний кодекс розробляли 3 урахуванням міжнародних вимог. Лікарі, науковці та адміністративний персонал, які мають безпосереднє відношення до наукової та лікувально-профілактичної в галузі охорони здоров'я та медицини повинні дотримуватися обов'язкового виконання цього кодексу. Збереження та захист життя й здоров'я людини в пренатальному і постнатальному періоді, профілактика захворювань i відновлення здоров'я та зменшення страждань при невиліковних хворобах, при народженні і настанні смерті - головна мета професійної діяльності лікаря (практика і вченого). Лікар, в повній мірі, несе відповідальність за свої рішення і дії щодо життя та здоров'я пацієнтів. Лікар служить гуманним цілям, які дозволяють йому вимагати законодавчого захисту моральноетичних позицій i принципів, особистої гідності, матеріального забезпечення та створення належних умов для здійснення фахової діяльності. Будь-яка професіаональна діяльність лікаря повинна спрямовуватися на досягнення максимально можливої користі для життя, здоров'я та соціального захисту пацієнта - це важлива умова, що корегується також умовами біоетики. [26]

Ще одним важливим питанням, яке обговорює цей кодекс, є наукові дослідження за участю пацієнтів. Лікарю обов'язково необхідна птсьмова згода уповноваженої етичної комісії або комітету які затверджують протокол або план для проведення біомедичних досліджень та апробації нових лікарських препаратів, а також проведення лікувально-діагностичних методів та обладнання. В ньому необхідно чітко визначити цілі проведення досліджень, послідовність протікання достіджень, етичні аспекти та ускладнення, які можуть виникнути в ході проведення досліджень. Лише при дотриманні вказаних умов можливе проведення досліджень 3 участю пацієнтів. I лише тоді, коли вони спрямовані на покращення здоров'я пацієнтів. Отримані результати матимуть особливий внесок в науковий та практичний розвиток медицини. Варто зазначити, що проведення досліджень можливо лише при позитивних результати попередніх досліджень, які окрім всього іншого, містять інформацію про можливі ризик розвитку ускладнень та повинні забеспечувати умови та необхідниі заходи для безпеки пацієнта. Тільки тоди проведення такого дослідження $є$ морально та етично доцільним. [26]

Етичний кодекс фармацевтичних працівників Украӥни - це документ, котри визначає етичні норми професійної поведінки та відповідальності фармацевтичних працівників за умов формування ринкових відносин. Відповідно до кодексу, встановлюють основні завдання щодо діяльності фармацевтичних працівників, якими являється збереження життя та здоров'я людини, а також охорони здоров'я та екосистеми в цілому. Метою кодексу являється обгрунтування та документування принципів що базуються на загальнолюдських цінностях. Кодикс орієнтований на захист гідності та прав людини, а також охорону здоров'я. Він визначає обов'язки та відповідальність працівників фармацевтичної галузі у процесі здійснення їх професійної діяльності. До складу кодексу входять норм фармацевтичної 
етики та деонтології, якими повинен керуватися фармацевт в ході здійснення кваліфікованої та якісної, доступної та своєчасної фармацевтичної допомоги населенню. Даний документ сприяє формуванню довіри до професійної діяльності провізорів i фармацевтів та підвищення їх статусу та іміджу. Даний кодекс розроблений з урахуванням офіційних матеріалів ВОO3, фармацевтичної групи $\mathrm{EC}$, Міжнародної фармацевтичної федерації та Міжнародної медичної асоціації. [27]

Окрім, зазначених вище кодексів існують окремі Накази Міністерства Охорони здоров'я, які регулюють відносини або використання речовин та методів у повсякденному житті людини. Наприклад, Наказ MO3 «Про затвердження Порядку здійснення контролю за відповідністю імунобіологічних препаратів, що застосовуються в медичній практиці, вимогам державних i міжнародних стандартів» регулює проведення контролю та механізми цього контролю відносно відповідності імунобіологічних препаратів вимогам державних i міжнародних стандартів, що застосовуються в медицині. [25, 26, 27]

Актуальність дослідження проблеми дбайливого ставлення до людини, рослинного i тваринного світів полягає насамперед у тому, щоб привити таке ставлення 3 самого дитинства, а потім підтримувати його у учнів ВУЗів та наукових працівників. Виховання свідомого ставлення молоді до природи в педагогіці має розглядатися як дійовий чинник різнобічного розвитку особистості. Необхідність охорони природи, бережливе та шанобливе ставлення до неї, що формуються у процесі навчання й виховання, дозволять особистості відчути себе органічною часткою довкілля, яка несе певну функцію у природі та суспільстві, допоможуть формуванню відчуття відповідальності за свою діяльність

\section{ХІІ. ВИСНОВКИ}

$\begin{array}{lcr}\text { Забеспечення } & \text { умов } & \text { безпечності } \\ \text { біотехнологічних } & \text { та } & \text { мікробіологічних } \\ \text { виробництв, являється ключовим завданням } \\ \text { біобезпеки. Біобезпека повинна досягатися }\end{array}$

шляхом застосування комплексу заходів для отримання, поширення, утримання, колекціонування та використання бідь-яких біологічних об’єктів. Заходи біобезпеки передбачають усунення всіх можливих джерел зростання ризику від використання лабораторій різного рівня біологічної безпеки, мікроорганізмів, генетично трансформованих організмів, медикаментів та виробів сільськогосподарського призначення. Біобезпека має гарантувати всебічне вивчення можливих небезпечних факторів, пов'язаних 3 конкретним організмами та їх практичним використанням 3 урахуванням ризиків. Повинні суворо регламентуватись правила транспортування, імпорту й використання генно модифікованих організмів, проходити обов'язкове позначення продукції, отриманої 3 ГМО, обмін відповідною науковотехнологічною, екологічною та правовою інформацією. Протокол передбачає передання технологій біотехнологічної промисловості в країни, які знаходяться на стадії активного розвитку. Зазначається, що будь-яке обмеження інформації, яке може затримувати передбачення можливих ризиків, є недопустимим. Окремо важливим пунктом є усвідомлення працівників сфер, що пов'язані $з$ питаннями біобезпеки, важливості дотримання правил та принципів етичності та моралі.

Робота виконана в рамках гранту Національного фонду досліджень України 2020.01/0464 «Розробка концепції підготовки фахівців та підвищення кваліфікації 3 біобезпеки та біозахисту».

\section{ХІІІ. ПЕРЕЛІК ПОСИЛАНЬ}

[1] Smith G. The role of scientists in assessing the risks of dualuse research in the life sciences / G. Smith, N. Davison, B. Koppelman; In: J. L. Finney, I. Slaus, editors. - Assessing the threat of weapons of destruction: The role of independent scientists. - Amsterdam : IOP Press, 2010. - P. 137-140

[2] Биологическая безопасность в микробиологических и биомедицинских лабораториях / Д. Абрахам, М. Адлер, Л. Алдерман и др. - Вашингтон : Типография Правительства США, 2007. $-360 \mathrm{c}$

[3] Відповідальні медико-біологічні дослідження в глобальнійбезпеці системи охорони здоров'я : методичний документ. - Женева :ВООЗ, 2010. - 70 с.

[4] 15.10. Guidelines for Biosafety in Teaching Laboratories Using Microorganisms / [Environmental Health and Safety]. - 
Bloomington :Publisher house of the Indiana University, 2013. $7 \mathrm{p}$.

[5] Тюрин Е. А. Факторы биологической безопасности / Е. А. Тюрин // Биозащита и биобезопасность. - 2010. - Т. II, № 3 (4). - C. 34-39

[6] Ishino Y., Shinagawa H., Makino K., Amemura M., Nakata A. Nucleotide sequence of the iap gene, responsible for alkaline phosphatase isozyme conversion in Escherichia coli, and identification of the gene product // Journal of Bacteriology. 1987. - Vol. 169, no. 12. - P. 5429 - 5433. - PMID 3316184 [7] Sontheimer E. J., Barrangou R. The Bacterial Origins of the CRISPR Genome-Editing Revolution // Human Gene Therapy. - 2015. - Vol. 26, no. 7. - P. 413-424. doi:10.1089/hum.2015.091. — PMID 26078042

[8] Немудрый А. А., Валетдинова К. Р., Медведев С. П., Закиян C. М. Системы редактирования геномов TALEN и CRISPR/Cas - инструменты открытий // Acta Naturae. 2014. - № 3 (22). - C. $20-42$.

[9] Job D. Plant biotechnology in agriculture (англ.) // Biochimie (англ.)русск. : journal. - 2002. - Vol. 84, no. 11. — P. 1105 - 10. - PMID 12595138

[10] Daniell H., Dhingra A. Multigene engineering: dawn of an exciting new era in biotechnology (англ.) // Curr Opin Biotechnol : journal. - 2002. - Vol. 13, no. 2. - P. 136 - 41. - PMID 11950565

[11] Guidance document for the risk assessment of genetically modified plants and derived food and feed by the Scientific Panel on Genetically Modified Organisms (GMO). Архів оригіналу за 2013-02-06.

[12] Nordlee JA, Taylor SL, Townsend JA, Thomas LA, Bush RK. (1996). Identification of a Brazil-nut allergen in transgenic soybeans.. N Engl J Med. 334 (11): 688-92.

[13] Ewen SW, Pusztai A (1999). Effect of diets containing genetically modified potatoes expressing Galanthus nivalis lectin on rat small intestine. Lancet 354 (9187): 1353-4.

[14] Marshall A. (2007). M soybeans and health safety - a controversy reexamined. Nature Biotechnology 25 (9): 981-987.
[15] 2005 Report on Enforcement of the Animal Welfare Act Архивная копия от 1 марта 2013 на Wayback Machine U.S. Department of Agriculture, accessed February 8, 2008

[16] Doidge, Norman. The Brain That Changes Itself. Viking Penguin, 2007, p. 141.

[17] Carbone, Larry. What Animals Want. Oxford University Press, 2004. pp. 90-91.

[18] "Group Says It 'Rescued' 260 Animals From Lab, " Associated Press, April 21, 1985.

[19] R. M. Schoch, Case studies in environmental science, Jones \& Bartlett Learning, 1996

[20] Barbara A Cohn, Piera M Cirillo, Mary Beth Terry. DDT and Breast Cancer: Prospective Study of Induction Time and Susceptibility Windows (англ.) // JNCI: Journal of the National Cancer Institute. - 2019-02-13. - ISSN 1460-2105 0027-8874, 1460-2105. — doi:10.1093/jnci/djy198

[21] Wilmut, I., Schnieke, A.E., McWhir, J., Kind, A.J., Campbell, K.H.S. Viable offspring derived from fetal and adult mammalian cells PMID 9039911 Nature, 1997 issue 6619 pages $810-813$ (англ.)

[22] K. D. Sinclair, S. A. Corr, C. G. Gutierrez, P. A. Fisher, J.H. Lee, A. J. Rathbone, I. Choi, K. H. S. Campbell, D. S. Gardner. (2016). Healthy ageing of cloned sheep. Nature Communications, 7, Article number: 12359 doi:10.1038/ncomms 12359

[23] Bikram Grewal. Birds of India, Bangladesh, Nepal, Pakistan \& Shri Lanka. - Hong Kong, New Delhi: Guidebook Company Ltd, Gulmohur Press Pvt Ltd, 1993. - C. 23. - 193 c. - ISBN 962-217-311-X.

[24] Vibhu Prakash, Mohan Chandra Bishwakarma, Anand Chaudhary, Richard Cuthbert, Ruchi Dave, Mandar Kulkarni, Sashi Kumar, Khadananda Paudel, Sachin Ranade, Rohan Shringarpure, Rhys E. Green. The Population Decline of Gyps Vultures in India and Nepal Has Slowed since Veterinary Use of Diclofenac was Banned (англ.) (PDF). US National Library of Medicine, National Institutes of Health

[25] Етичний кодекс ученого України | от 15.04.2009 № 2

[26] Етичний кодекс лікаря України

[27] Етичний кодекс фармацевтичних працівників України 


\section{УДК 608.1+608.32 \\ БИОБЕЗОПАСНОСТЬ И БИОЭТИКА \\ КАК ЭЛЕМЕНТЫ \\ ПРОФЕССИОНАЛЬНОГО \\ МИРОВОЗЗРЕНИЯ}

Фешина М.A.

feshyna-fbmi@111.kpi.ua

Беспалова А.Я., к.б.н., с.н.с.

e.bespalova25.05@gmail.com

Бесараб О.Б., к.т.н.

o.besarab@kpi.ua

Национальный технический университет Украины «Киевский политехнический институт имени Игоря Сикорского»

г. Киев, Украина

Реферат - В наше время развитие науки и промышленности требует новых подходов к решению вопросов безопасности, особенно когда это касается жизни человека. Негативные последствия деятельности человека, особенно при работе с различными биологическими объектами, являются потенииальной угрозой как для жизни и здоровья человека, так и для окружающей среды, из-за которых развиваются стандарты биобезопасности во всем мире.

Статья посвящена анализу существующих рисков биобезопасности, в том числе таким актуальным темам как редактирование генома CRISPR, технология рекомбинантных ДНК, влияние ГМО, клонирование. Также акцентировано внимание на возникновении экологических катастроф, связанное с несоблюдением мер по безопасному использованию аспектов биобезопасности. Важным аспектом, который поднимается в статье, является морально-этическая составляющая поведения профессионалов в сфере биотехнологии, микробиологии и медицинской биоинженерии, которая регулируется с помощью существования кодексов. Статья освещает актуальные проблемы биоэтики и биобезопасности и подчеркивает необходимость улучшения соответствующих правил, кодексов и требований.

Ключевые слова: биобезопасность, биоэтика, риск, редактирование генома, биотехнология 


\title{
BIOSECURITY AND BIOETHICS AS ELEMENTS OF A PROFESSIONAL WORLDVIEW
}

\author{
Feshina M.O. \\ feshyna-fbmi@111.kpi.ua \\ Bespalova O.Ya., Ph.D., Senior Research Fellow \\ e.bespalova25.05@gmail.com \\ Besarab O.B., Ph.D. \\ o.besarab@kpi.ua \\ National Technical University of Ukraine "Kyiv Polytechnic Institute named after Igor Sikorsky" \\ Kyiv, Ukraine

\begin{abstract}
Nowadays, the development of science and industry requires new approaches to addressing security issues, especially when it comes to human life. The negative consequences of human activities, especially when working with a variety of biological objects, are a potential threat to human life and health, as well as to the environment, due to which biosafety standards are being developed around the world.

The article is devoted to the analysis of existing biosafety risks, including such relevant topics as CRISPR genome editing, recombinant DNA technology, GMO exposure, cloning. Emphasis is also placed on the occurrence of environmental disasters, which are associated with non-compliance with measures for the safe use of aspects of biosafety. An important aspect raised in the article is the moral and ethical component of the behavior of professionals in the field of biotechnology, microbiology and medical bioengineering, which is regulated by the existence of codes. The article highlights current issues of bioethics and biosafety and emphasizes the need to improve relevant rules, codes and requirements.
\end{abstract}

Key words: biosafety, bioethics, risk, genome editing, biotechnology. 